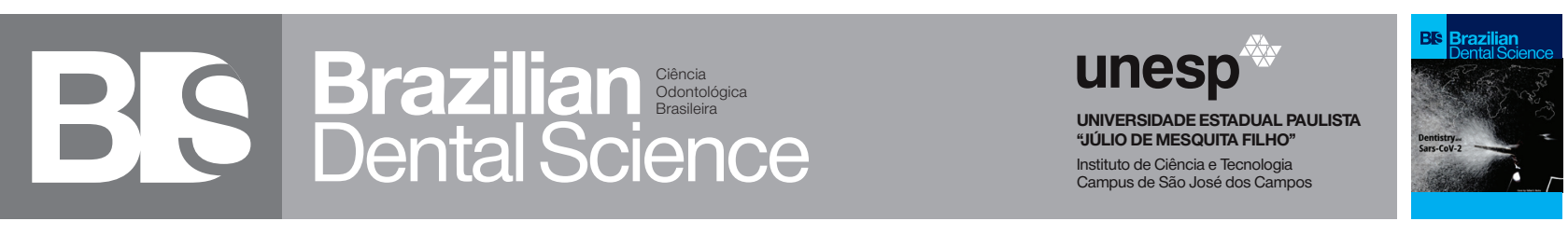

\title{
The importance of dental office management in times of COVID 19 and how to resume activities in post-pandemic
}

A importância da gestão do consultório odontológico em tempos de COVID 19 e como retomar as atividades pós pandemia

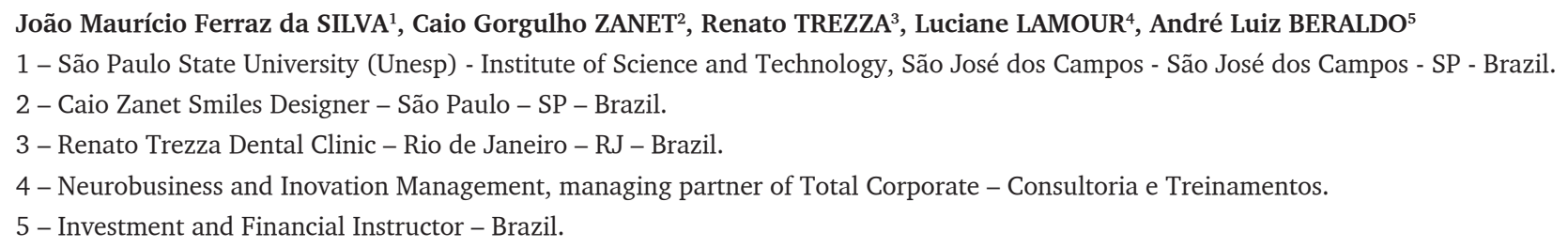

\begin{abstract}
We are going through a health crisis, a pandemic caused by the new corona virus (SarsCOV2), which causes the disease COVID 19. This pandemic has also had a negative impact on the world economy, with dental offices being directly affected. Given this, the objective of this article is to bring important points in the strategy of management of dental clinics and how to be prepared to face the moment of crisis and also for the resumption. We believe that actions should be guided on three fronts: survival, sustainability and new future. The scenario is new, but with the right actions, the prospects for recovery are good. The important thing is to stay focused on what we have control, to do our best for the financial health of the business, however, remember that human health comes first, that any financial recovery will only be positive when people's lives and health are being preserved.
\end{abstract}

\section{KEYWORDS}

Corona virus; Business management; Financial management.

\section{RESUMO}

Estamos passando por uma crise de saúde, uma pandemia causada pelo novo corona vírus (SarsCOV2), causador da doença COVID 19. Esta pandemia, trouxe um impacto negativo também na economia mundial, sendo os consultórios odontológicos diretamente atingidos. Diante disso, o objetivo deste artigo é trazer pontos importantes na estratégia de gestão de clínicas odontológicas e como estar preparado para enfrentar o momento de crise e também para a retomada. Acreditamos que as ações devam ser pautadas em três frentes: sobrevivência, sustentabilidade e novo futuro. $\mathrm{O}$ cenário é incerto, porém com ações acertadas as perspectivas de retomada são boas. O importante é mantermos o foco naquilo que temos controle, fazer nosso melhor para a saúde financeira dos negócios, porém, lembrar que a saúde humana esta em primeiro lugar, que qualquer retomada financeira só será positiva quando as vidas e a saúde das pessoas estiverem sendo preservadas.

\section{PALAVRAS-CHAVE}

Corona virus; Gestão de negócios; Gestão financeira. 


\section{INTRODUCTION}

W

e are experiencing something unusual in our society, at least for the generations that still inhabit the Earth. A war against an invisible and relatively unknown enemy. In December 2019, a new disease emerged in Wuhan, China, which spread rapidly to 24 countries [1]. This new disease, called COVID 19 , is caused by the new Corona Virus (SarsCOV 2 ), which has a very strong transmission rate, a fact that spread the disease to all continents, leading the WHO (World Health Organization] to declare a public state of emergency and after a pandemic $[2,3]$.

Since the beginning of the pandemic, the numbers are alarming, today, we have almost 7 million confirmed cases, with 400,000 deaths worldwide. [4]. With the advancement of the disease and the risk of death for many people, the governments, together with the Ministry of Health and WHO, proposed their strategies for the preservation of life, a fact that, at this moment, should be the main focus. The strategy, most used by most countries, and which had interesting results with regard to the progress of the disease, was social isolation. In this strategy, the population was instructed to stay at home and only essential activities should be maintained, however, with no rules and punishments established for those who did not follow the guidelines. In some locations, where the spread of COVID 19 was more quickly, a lockdown was established, in which people could not really leave the house, with the risk of receiving penalties, in the form of a fine, for not complying with the requirement [5].

Regardless of which strategy was used, this whole situation had an impact on the economy of all affected countries, COVID 19 drastically flattened the world economy, with an estimated loss of 1 trillion US\$ during the year 2020. The closing of the trade, reduction of business activities, reduction of circulation between countries, finally, a strategy of social distancing, negatively impacts all branches of the economy, due to a series of factors. A fact that is worrying, since population health is also dependent on a healthy economy, these two aspects must walk together, especially when referring a extreme poverty niche in society $[6,7]$.

In the dental field, this negative economic impact, from the reduction of activities, is also happening. The recommendation, since the beginning of the pandemic, is that the elective appointments should be interrupted, being directed only to the emergency attendance, which drastically reduces the economic capacity of most dental offices. In addition, the population's own fear of leaving home leads to a decrease in the flow of patients, which also generates negative results for the office cashier.

Given this scenario, this article aims to bring some management and marketing strategies, discussed by experts in the field, for the conduct of dental offices in this pandemic context and how to organize an economic recovery in the post-pandemic.

\section{MOTIVATIONAL STRATEGIES}

In a difficult phase, where our routine is suddenly transformed, and where we are "forced" to be separate from our families and friends, and added to that, we also cannot exercise our professional activity in the same way as before, the psychological aspect of the human being can logically be affected. It is than interesting to focus on what is possible to be accomplished, to spend our energy on what we have control over. The things, in which we cannot have decision-making command, should not be the focus of our actions, since it would only be spent of energy without any concrete result as an answer.

Focusing on what we have control, we consider essential to take care of our mental state, to work our feelings so that we can we can overcome this phase in the best possible way. One way to control our psychological aspect, would be to feel active, even though we 
are not attending patients as often as before. Being in the office, with the team, studying the strengths and weaknesses of the business, is a way to motivate and better prepare for the moment experienced. Allied to this, we need action; there is no sense in having ideas and not putting them into practice. The moment now is to plan, to reinvent, but mainly, to move, so that these changes take place. Due to the high clinical demand of professional dental surgeons, it is common that there is no time for this strategic alignment of business and market, perhaps this is the time, for those who have this gap, to leave their comfort zones and promote concrete actions in this area

\section{CLINICAL OPERATING STRATEGIES}

Without a doubt Dentistry will change with this pandemic, in several aspects. It is important that the dental business have this vision, in order to have a great chance of economic recovery. The issue of reinventing oneself is extremely important in this sense, the focus of this change must always be the patient, he is the most interested in this process, all of our actions must be focused on him.

Within the context of focusing on the simple, on what is possible, we can exercise a supportive action to our patients. Contact each one of them, showing concern for the current situation, wanting to know about his health and making yourself available for any eventual need he may have in terms of oral health. This type of action can attract patients at this time, in addition to making your client even more loyal to a future moment of need.

One aspect to be changed, are the issues of biosafety, new service protocols are being suggested, due to the high transmission capacity of the new virus, mainly in a dental environment [8]. The dental office environments, have always been very biosafety, due to the great risk of contagion from other diseases. At the present time, these actions must be complemented with additional care, in order to reduce the risks of transmission from the dental team to patients and vice versa, in addition to less transmission from patient to patient [9]. In addition to this main objective, we can use this new care to our advantage, in terms of business. We can value this aspect, in communication with patients. Any action in this sense, whether by the acquisition of new equipment that promotes a more sanitized environment, or by the simple change of routine on the arrival of patients, care with the staff's individual protection, must be evidenced with the patient, so that he realizes this concern of the company with the client, making him feel important and confident in undergoing dental treatment even in times of pandemic. Logically, this approach must be careful and in an appropriate way, we cannot generate fear in the patient, but rather create a way to acquire his confidence that there is an environment prepared to take care of him without causing risks to his health.

A clinical aspect, that we must adapt in this phase of changes, is the optimization of dental procedures. The routine of caring a large number of patients per period should be modified, the trend will be few visits on the day with longer duration, so that there is less circulation of people in the office environment. For this, an adaptation in the clinical routine of many offices will need to be adjusted, logically each one within the reality of the public it serves, but we see possibilities, in this sense, for any demand. The important thing will be, to establish a concrete treatment plan, with beginning, middle and end. In the initial phase of the treatment, establishing an adequate case planning, the clinical phases can be carried out in an orderly and objective way. In this way, the optimization of procedures will be facilitated and the patient's discharge will be accomplished in a shorter treatment time.

Another important aspect in the resumption, within the clinical practice, is to understand that the patients' demand will be different. The focus should be on prevention 
and rapid problem resolution, since patients, even after the pandemic, will be restricted to leaving home, at least in a first moment. Elective treatments, such as aesthetics, for example, should not be a priority for clients, therefore, we suggest a change of focus, to a more preventive and resolving approach, promoting the health and comfort of patients, in addition to offering less costly treatments, with greater payment possibilities since the economic lag will reach everyone.

Therefore, within a clinical perspective, these are scenarios that professionals must begin to understand and put into practice for a readjustment to a new reality.

\section{MANAGEMENT STRATEGIES IN TIMES OF CRISIS}

Within a strategy of going through an economic crisis and resuming after a difficult scenario, the first point is that the dentist needs to see his office as a company, this is essential to start winning the game. We need to assume our responsibility as manager, we must not place the blame on the outside factors and use this as an excuse to stay in our comfort zones.

The big issue of the business strategy is that we are in a period, where the redesign of our business has become something essential. The real fact is that the future, where all this situation will take us, is relatively uncertain, however, what can not be is procrastination, we must work with the information we have to start this necessary change, and this is the great challenge. For example, people's routine and form of consumption is already different, and in a future moment it will change again, so our strategies, established in the prepandemic, needs to be changed as well. Given this, we can say that the reinvention, in this current scenario, resembles a startup, where the model needs to be tested, going to the field and testing new strategies, as already mentioned, new clinical approaches, new forms of payment among other actions.
Leaving the technical context, it is important that the dental surgeon assume his role as manager of his company, since the main point of adjustments and changes, at this moment, is directed to management and sales. We must think about 3 fronts at this point, firstly, about survival, our business needs to survive, what actions can we guide in this direction? The example mentioned above, of supporting the patient, showing attention, relating to your patient at this time, makes you keep him close to you and this will bring survival to your company. Second aspect to be worked on, is the sustainability of your business, we need to align survival with maintenance, perform actions on services and products that are sustainable at least in the medium term. And finally, thinking about a new future, despite the great social and health problem, in terms of business, crises, even being challenging, are opportunities to design this new future that can be very good. In order to achieve these fronts, we need to optimize, use our time for adjustments, solve problems, there should be no waste. In addition, within this reinvention of our management and business, it will often be necessary to develop new skills so that we can implement all the changes that we are aiming for.

The management of a business, goes through several areas, important for the success of a business, important to develop our skills in each of them:

SALES: it is considered the heart of any business. In this sense, the health professional needs to change his mindset, that concept that "health" is not necessary to sell, that is a service that sells itself is outdated, the market has changed, this no longer fits in the current world and less still going forward. The change in thinking that we have to have is not to see selling as a way to convince someone to purchase a service or product, but rather to help your customer to make a good decision for him. We have the responsibility to offer something that we consider necessary for the patient, we will help him to make the decision, 
since he may be undecided, or help in the sense of acquiring that service, extremely necessary for him, at that moment, not allow him to postpone. Within sales, important aspects must be emphasized, customer loyalty, taking care of our patient portfolio, which is the greatest asset of an office. We must review our value and market proposal, with regard to the services provided and customer profile, see what is essential at the moment, optimize your treatments and facilitate the form of payment.

MARKETING: it is known that in the dental field, in order to be successful in terms of clients, the professional must not only be good technically, but it is also necessary to show that you are good, for that you need to appear, and for that are the marketing strategies. It is necessary to rethink marketing, check channels to create authority and attract customers.

OPERATION: a patient will not give the dentist the opportunity to show all his technical ability, if this client is not captured, and for that he needs to have a pleasant experience in your environment, from the telephone answering by the secretary at the time of the appointment scheduling, until the time he leaves your office. Therefore, a well-aligned operation is necessary, welltrained teams, effective internal and external communication, establishing important partnerships, contributing to an effective process for the entire business.

STRATEGY: to put any strategy into practice, planning is necessary, any action, when well planned, tends to have a better chance of being successful. Thinking about strategic planning, at the present time, thinking about immediate and future actions, we are not sure of anything, but we need to plan a route so that we can evaluate what worked and what did not. If we have not planned, we may find ourselves lost along the way. Having an objective, in case we deviate from the route, it will be easier to return towards the strategically outlined goal. This entire business model must be based on planning, a division between operational (clinical practice) and strategic planning is important. It is essential that health professionals, have the discipline to plan their business at all times, set aside periods to develop strategies with the intention of maintaining the company's health.

TEAM: it is important at this point to take care of the team, regardless of number of people, you need to keep them close to you. Take care of the emotional side, they are scared, insecure in terms of health and financial. Within the planning, bring intelligent solutions, motivate, value, support your team, this is essential for survival and especially for ambitions of recovery.

LEADERSHIP: take care of yourself as a leader. Do a self-leadership exercise, always positive, optimistic, strategic and courageous, challenge yourself to do different things, outside from your comfort zone. Eventual falls can happen, but we have to do, learn, take risks so that we can overcome this phase and move on.

This whole issue of managing a company, in the current and future world, should bring some emotions together, we believe that this will be the differential of many businesses in view of the technological advancement and the sedimentation of industry 4.0.

We must try, at all times, to bring to our environment, a feeling of compassion, even more in this lived scenario, helping people is essential, thinking in an opposite way, it maybe is, even, an inhuman act. We also need to trust, in all spheres, leader, team, client, partners, in short, trust in all directions, which will result in security, which is another necessary feeling within management in times of crisis. And finally, hope, it can never be lost, it will maintain the vitality to follow and overcome all difficulties on the way.

\section{FINANCIAL MANAGEMENT}


We leave a separate chapter for the financial question within the office management planning in times of crisis. Logically it is part of the general context, but it is worth to be highlighted. The first point in this sense is the professional, once again understanding that the dental office or clinic is a form of business, and every business needs to generate profit. For profit to exist, three things are needed, marketing and sales, which have already been discussed, and financial management.

Within financial management, we need to understand that the health of a business depends on its profitability. To calculate profit, in a simple way, we must take a company's income, that is, how much money goes into the company's cash, we subtract all expenses, everything that comes out of the cash and then we get the total profit. Of course, when the result is positive, we have profit, but in times of crisis, we can face a cash flow problem, when our expenses exceed the incomes. All aspects discussed above were intended to take action in order to overcome difficult times in a business. In the current scenario, where we were "forced" to stop our professional activities for a while, if we do not act, do not take any strategic action, what will happen to our expenses? They will remain, since fixed expenses are the largest percentage of a company's monthly expenses. On the contrary, as we are at a standstill, our revenues decrease a lot, consequently our profit becomes negative. At this time, there is a need to inject private capital or the company's emergency reserve, if any, to maintain the health of the business. At this point, it is important to emphasize the need for a financial organization, construction of an emergency reserve, both personal and professional, for you to prepare for these moments, to be able to overcome these phases in a more peaceful way.

Therefore, in a scenario where we see our receipts going down, the first action should be to try to reduce expenses. Being effective in this reduction of expenses, we can avoid a negative profit, which is important for survival. There are several ways to reduce expenses, government plans to reduce the workload of the team, negotiate with suppliers and lessors, in resume, reduce expenses to the maximum, so that you stay away from a negative cash flow.

Another aspect within this simple financial management account, so that we can avoid negative profit, that is, loss, we can take actions to increase incomes.

Within the strategy of increasing revenues, we have to understand some aspects. Important questions are, who are our patients? Why did they come to us? What's going on with the office's incomes? What is happening with the office expenses? It is important to understand why patients chose to treat with you, what motivated them to become your client, this feedback will be important for you to set up your future client acquisition strategies. In the strategic plan we can establish more actions, we must challenge ourselves, always ask ourselves: how can I get more patients? How can I earn more in my clinic hours? How can I make my patient more satisfied? How can I do to grow my office/ business?

Mastery can help you generate more revenue for your business. Mastery, by definition, would be to have a positive result but with minimal effort. This stage is reached with a longer performance time, with study, repetition, where you improve your performance, which requires a lot of effort. At any given time, only a minimum effort will be expended for you to achieve optimal results, this is the stage of Mastery. From this moment on, you can bring new models to your business, which will be more easily implemented, since you have already acquired the experience for this, and in this way, you bring more revenue to your financial management.

In summary, the actions that can be effective in the pursuit of this increase in revenues would be:
- Increase your mastery;
- Develop the strategic;
- Activate your patient base;
- Offer something new to your base;
- Reinvent your way of working; 
campaigns, partners)

- Improve your sales.

\section{FINAL CONSIDERATIONS}

Within the current economic scenario, facing a pandemic, we come across an uncertain future, which causes fears and insecurity in people. In a situation like this, we need to rethink our business, in the form of strategic actions, based on three aspects: survival, sustainability and new future. For that, we need to operate, get out of comfort, reinvent ourselves, we need to go to the field to be able to see the scenario, seek answers, map it and then adjust the path towards the final goal, the health of your business, which will provide us financial freedom. This is the stage where you work for pleasure, by purpose, without the pressure of financial need.

We believe in a favorable economic scenario, the economic return, in our view, may bring a repressed demand. This phase is acting as a spring that is contracted, and when it is released, we will have to be prepared to absorb this demand, which makes us to believe in excellent recovery results.

In this moment, the important thing is to stay focused on what we have control, to do our best for the financial health of the business, however, remember that human health comes first, that any financial recovery will only be positive when people's lives and health are being preserved.

\section{Acknowledgement}

This article was extracted from an online discussion held between the authors on the subject in question, on $21 / 05 / 2020$, promoted by "Projeto Odonto no Boteco". In this way, we thank the team for the opportunity to turn the conversation into an article and to share important points regarding the management of dental offices and how to overcome moments of crisis.

\section{REFERENCES}

1. Peng X, XuX, Li Y, Cheng L, Zhou X, Ren B. Transmission routes of 2019-nCoV and controls in dental practice. Int J Oral Sci. 2020;12(1):9. Published 2020 Mar 3. doi:10.1038/s41368-020-0075-9

2. Xu H, Zhong L, Deng J, et al. High expression of ACE2 receptor of 2019-nCoV on the epithelial cells of oral mucosa. Int J Oral Sci. 2020;12(1):8. Published 2020 Feb 24. doi:10.1038/s41368-020-0074-x

3. Bi Xiaoqin, Xiong Maojing, Chen Lixian, Bai Yuanyan, Tian Li, Yang Hui. Nursing prevention and control of the novel coronavirus pneumonia in oral and maxillofacial surgery. Int J Stomatol. 2020;47(2):244-48. doi: 10.7518/ gjkq.2020054

4. COVID-19 pandemic by country and territory [Internet]. Avaiable at: https:// en.m.wikipedia.org/wiki/Template:COVID-19 pandemic_data

5. Schwendicke F, Krois J, Gomez J. Impact of SARS-CoV2 (Covid-19) on dental practices: Economic analysis [published online ahead of print,2020 May 27]. J Dent.2020;103387. doi:10.1016/j.jdent.2020.103387.

6. Bohoslavsky JP.COVID-19:Urgent appeal for a human rights response to the economic recession. [Internet] United Nations Humans Rights Special Procedures, Geneva.2020.21p. Avaiable at:https://www.ohchr.org/ Documents/Issues/Development/IEDebt/20200414_IEDebt_urgent_appeal COVID19 EN.pdf

7. Kabir M, Saqib MAN, Zaid M, Ahmed H, Afzal MS. COVID-19, economic impact and child mortality: A global concern [published online ahead of print, 2020 May 30]. Clin Nutr.2020;S0261-5614(20)30262-4. doi:10.1016/j.clnu.2020.05.027

8. Ather A, Patel B, Ruparel NB, Diogenes A, Hargreaves KM. Coronavirus Disease 19 (COVID-19): Implications for Clinical Dental Care. JEndod. 2020;46(5):584595. doi:10.1016/j.joen.2020.03.008

9. Cunas ITC, SilvaET, Santiago SBS, Maia KD, Silva-Junior GO. Coronavirus disease 2019 (COVID-19): A preventive approach to Dentistry. Braz J Dent. 2020;77:e1766. doi: http://dx.doi.org/10.18363/rbo.v77.2020.e1766. 